\title{
半側顔面痙卛の MRIによる検査法
}

\author{
坂 本肇-中 村 修-吉 沢和 弥 \\ 熊 谷. 博司・内山。暁 \\ 山梨医科大学医学部付属病院放射線部
}

(論文受理１992年 3 月23日）

（最終論文受理１992年 9 月18日）

(Code No. 640)

Key words: Magnetic resonance imaging (MRI), Hemifacial spasm, Oblique sagittal image, Dorsal brain stem

\section{MRI OF HEMIFACIAL SPASM}

\author{
Hajime Sakamoto, Osamu Nakamura, Kazuya Yoshizawa \\ Hiroshi Kumagai Gyou UCHIYAMA \\ Departmant of Radiology, Yamanashi Medical College Hospital
}

\section{Summary}

In cases with hemifacial spasm conventional MRI scanned by coronal or axial image has been limited to the visualization of large vessels compressing the facial nerve.

We therefore examined an oblique sagittal (OS) imaging method which was developed to provide better visualization process of vascular compression of nerves.

Our OS views were scanned along the nerve identified by the axial view, which was scanned at $105^{\circ}$ to the lines along the dorsal brain stem and the pontomedullary junction. The axial plane, scanned at $105^{\circ}$ to this baseline, permits the facial nerve to be clearly delineated in a high percentage of cases.

The OS gradient echo was utilized to understand the most clearly visualized compression of the nerve as high intensity line, even if the compressing vessel was smaller than those of the shown previously. This technique also made it easier to visualize the locations and directional of vessels, which compresses the nerves.

By studying the slice directions and imaging parameters and setting the baseline, we have improved the accuracy of MRI examinations using our method which provides effective preoperative data for hemifacial spasm. 


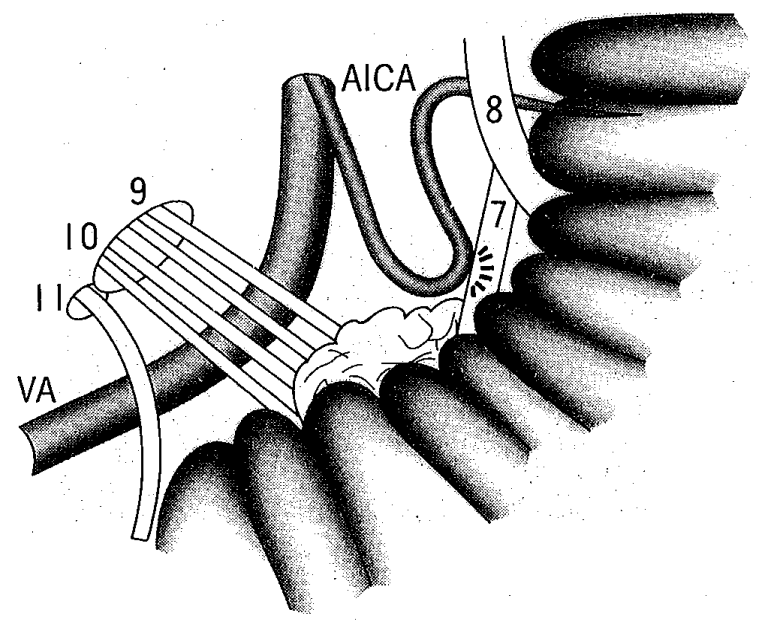

Fig. 1 Relations of the facial nerve and the compressed vessel Hemifacial spasm is occured due to cross arterial loop for compressing the facial nerve at root exit zone. VA: Vertebral Artery AICA: Anterior inferior cerebellar Artery 711 : Cranical nerves

対する評価も確立しつつある. MRI の進歩は, 従来より 行われて来たCT スキャンや，脳血管撮影では得られな かった多くの情報を非侵襲的に与えてくれる。

半側顔面痓卛は Fig. 1 に示すように, 顔面神経の脳幹 部出口への動脈圧迫 ${ }^{12)}$ によるもので, MRI の特異性に より両者の関係を直接的に描出することが可能となった. 以前よりこれに関する報告3) は) はあるが，撮影方向が横 断面あるいは冠状断面によるため, 安定した神経の描出
には制限があったまま，血管の太い椎骨動脈（Vertebral Artery：VA）は描出されることもあるが, 前下小 脳動脈 (Anterior Inferior Cerebellar Artery：AICA) や後下小脳動脈 (Posterior Inferior Cerebellar Artery： PICA)など細い血管の場合には描出されにくく，直角に 屈曲する拍動性圧迫 (Cross compression) や平行に圧迫 (Parallel compression) する場合!1 など，圧迫方法や方 向が複雑な関係を呈しているため描出は安定していなか った.

半側顔面病攣の治療法である神経血管減圧術78) を行 う術前検査として, 神経と血管の関係をできる限り明ら かにすることが必要であり，われわれは両者の位置関係 の描出に適した撮影方向及び，撮影条件を検討した。ま た本撮影を再現性よく的確にかつ簡便に行うため, 基準 線を設定し，位置決めの精度を検討したので報告する。

\section{2. 撮影方法}

\section{1 撮影方向及び手順}

神経と血管の関係を同時に描出する方法として Fig. 2 に示すように顔面神経の 2 平面での観察が最良であると 思われる. 2 平面を臨床で撮影するため, 以下の手順を 行った.

a. 頭部正中矢状断像の撮影 (Fig. 3-a)

b. 矢状断像を基に, 顔面神経の描出に優れた横断像 の撮影 (Fig. 3-b)

C、横断像に描出されている顔面神経にそつた斜位断 像 (以後ここでは「斜位矢状断像」という) の撮影 (Fig. 3-c)

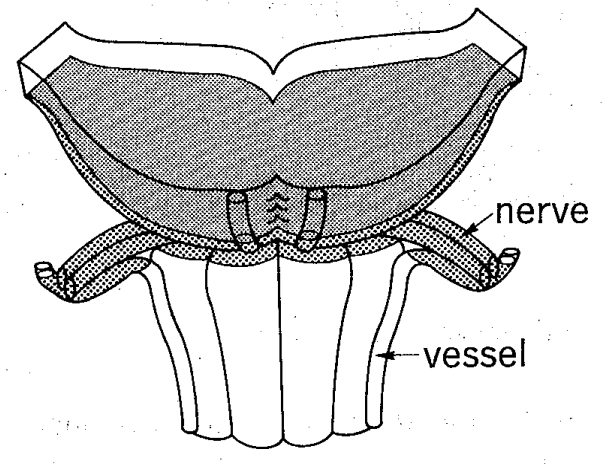

(a)

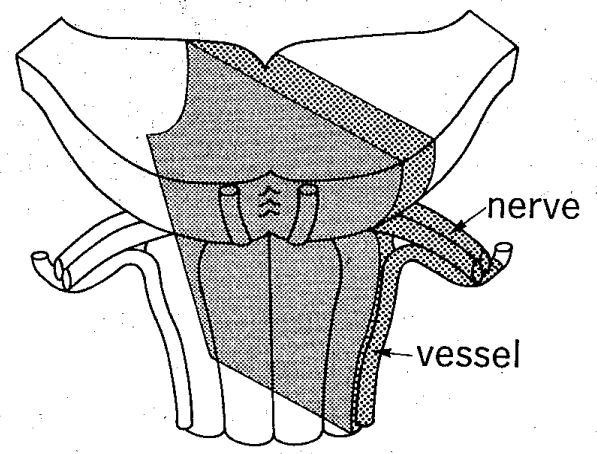

(b)

Fig. 2 The schema of imaging orientation a, axial image b, oblique sagittal image Imaging with the orientation like Fig. $2 b$, both the nerve and the compressed vessel can be obtained without the oppressed position. 


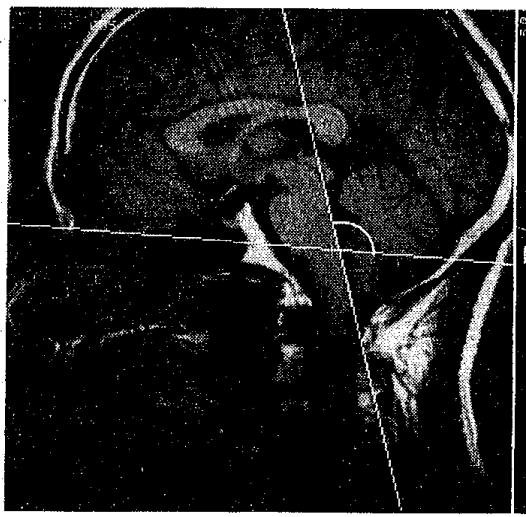

(a)

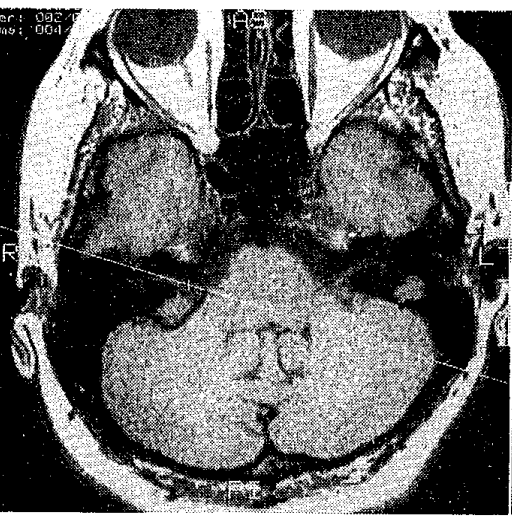

(b)

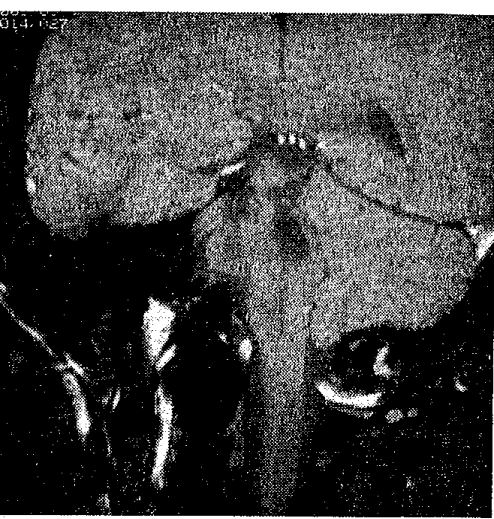

(c)

Fig. 3 Imaging orientation

a, sagittal image

b, axial image

c, oblique sagittal image

An axial image is taken based on the median slice of cranial sagittal imaging. An oblique sagittal image is scanned along the nerve identified by the axial image. Fig. 3 shows the degree of the change between the dorsal brain stem and axial slice plane that uses to change sagittal for axial image.

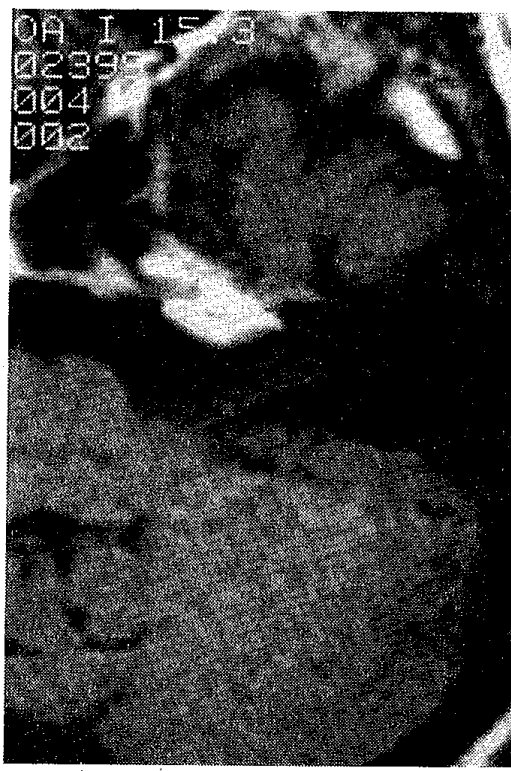

(a)

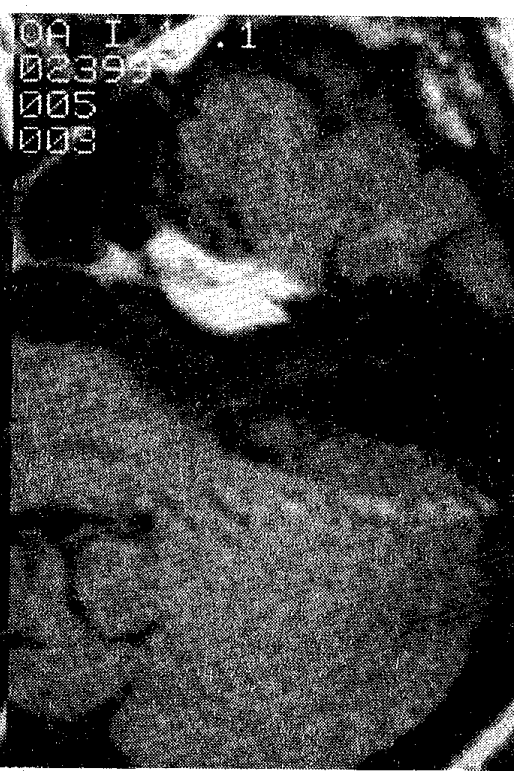

(b)

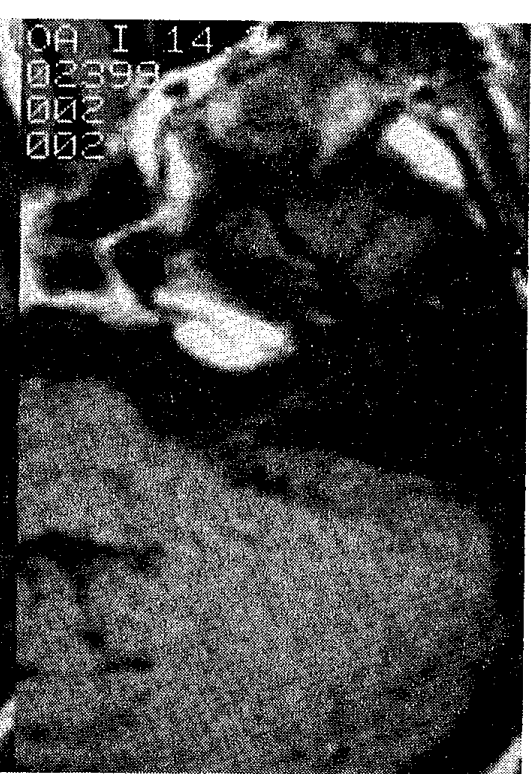

(c)

Fig. 4 The descriptive classification of the facial nerves into 3 levels. a, Excellent Image

The best image which can described by the facial nerve from the truncus cerebris exit to the internal auditory meatus.

b, Acceptable Image

The image can be used at least to localize the subsequent measurement.

c, Poor Image

The nerves cannot be addressed acurate because the nerve is shown only partially. 
なお, 使用機器は $\mathrm{GE}$ 社製 Signa $1.5 \mathrm{~T}$ にて頭部専用コイ ルを用いた。

\section{2 基準線と横断面の関係}

断面変換を正確かつ再現性よく行うため, 基準線を Fig. 3-a に示す延髄後縁（脳幹後縁）に設定した。

基準線と横断面の関係を調べるため, 当院にて施行さ れた頭部 MRI のフィルム上にて再検討し，顔面神経(聴 神経も含む) の描出されていた76症例について, Fig. 3aに示すように基準線とスライス面との角度を測定した。

\section{3 設定角度の精度}

2.20 結果より設定した基準線からの角度の精度を調 ベるため患者及びボランティア，34例68側にて基準線よ り設定した角度で横断撮影を行った。得られた画像から， 顔面神経の描出の程度により Excellent image（Fig.4$\mathrm{a}$, 顔面神経の脳幹出口より内耳道入口まで明瞭に描出 されている最適画像), Acceptable image(Fig. 4-b, 次 に行う撮影の位置決めができる最低限度の像), Poor image (Fig. 4-c，一部しか神経が描出されていないため 位置決めができない像）の 3 段階に分類し設定角度の評 価をした。

\section{4 神経の描出許容範囲}

横断像の Excellent imageよりスキャン角度を変化 させ，神経の描出許容範囲を検討した，対象はボランテ イア16名である. またここでいう描出許容範囲とは, 次 に行う斜位矢状断像への変換可能な画像の範囲である.

\section{5 撮影条件}

横断像は神経の描出に優れている $\mathrm{SE}$ 法の $\mathrm{T} 1$ 強調像 を用いた。斜位矢状断像は, 神経と血管の両者を描出し なければならないため $\mathrm{GE}$ 法を用いた。 GE 法の場合, TR，TE，Flip angle の組み合わせにより，画像が大き く変化するため最適条件の検討を行った。 なお, 横断像 の撮影条件は, TR： $500 \mathrm{msec}, \mathrm{TE} ： 20 \mathrm{msec}$, FOV : $20 \sim 16 \mathrm{~cm}$, マトリックス: $256 \times 192$, 加算回数： 2 回, スライス厚： $3 \mathrm{~mm}$ のギャップレスである.

\section{3. 結 果}

\section{1 基準線と横断面の関係}

Fig. 5 は基準線と横断面とのなす角度と件数の関係を 示している.スライス角度は 90 １18度まで幅広く分布し ているが, 105度を中心として前後 3 度の間に全体の約50 \%が分布している。このため設定角度を105度とした。

\section{2 設定角度の精度}

設定角度の評価を行った結果 Excellent と Acceptable image は次に行う斜位矢状断撮影時の位置決めが

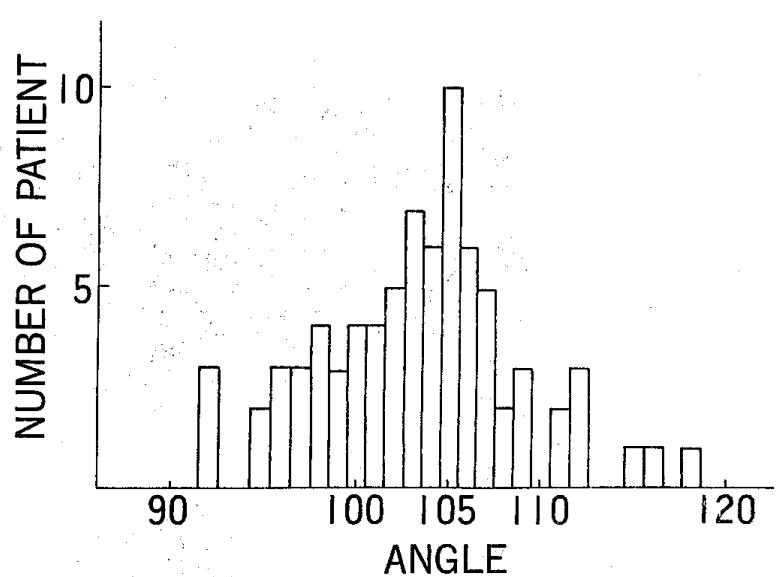

Fig. 5 The angle between the dorsal brain stem and axial slice plane

We have investigated 76 cases. The angle of the slice is distributed frem 90 to 118 centered on 105 .

可能な像で全体の約 $90 \%$ となったままた顔面痙攣患者に おいても同等な評価となった。

\section{3 神経の描出許容範囲}

Fig. 6 は最適画像より角度を微少変化させ撮影を行っ た症例を示す。この症例の場合 105 度が最適画像であり, 100,103 度では脳幹部付近の神経, 110 度では内耳道が描 出されているにすぎず，次の撮影の位置決めを行うには 不的確である。これより描出許容範囲は104度から107度 までの 4 度となる。同様に16名を測定した結果，個人差 はあるが，許容範囲は 4 〜 度となった。

\section{4 撮影条件}

$\mathrm{GE}$ 法の撮影条件として, TE を最小時間の $20 \mathrm{msec}$ と し, TR を60，100，200，300, $500 \mathrm{msec}$, Flip angle を 5〜90度にて比較した。

Fig. 7 は TR300 msec, TE20 msec一定とし Flip angle を 5 90度変化させ撮影した画像より神経と血管 の Flip angleに対する信号強度を測定した結果である.

\section{4. 臨 床 例}

症例 1 正常例, 35才, 男性

Fig. 8 は正常例の GE 法による斜位矢状断像を示す。顔 面神経付近には血管像を認めない。

症例 2 半側顔面病攣患者, 66 才, 女性

臨床症状にて半側顔面病摹の症状があり MRI 検査後, 神経血管減圧術を施工している.Fig.9 は GE 法による 斜位矢状断像を示す．顔面神経の脳幹出口付近八の血管 の圧迫が認められる。

症例 3 半側顔面凐攣患者, 73 才，女性 


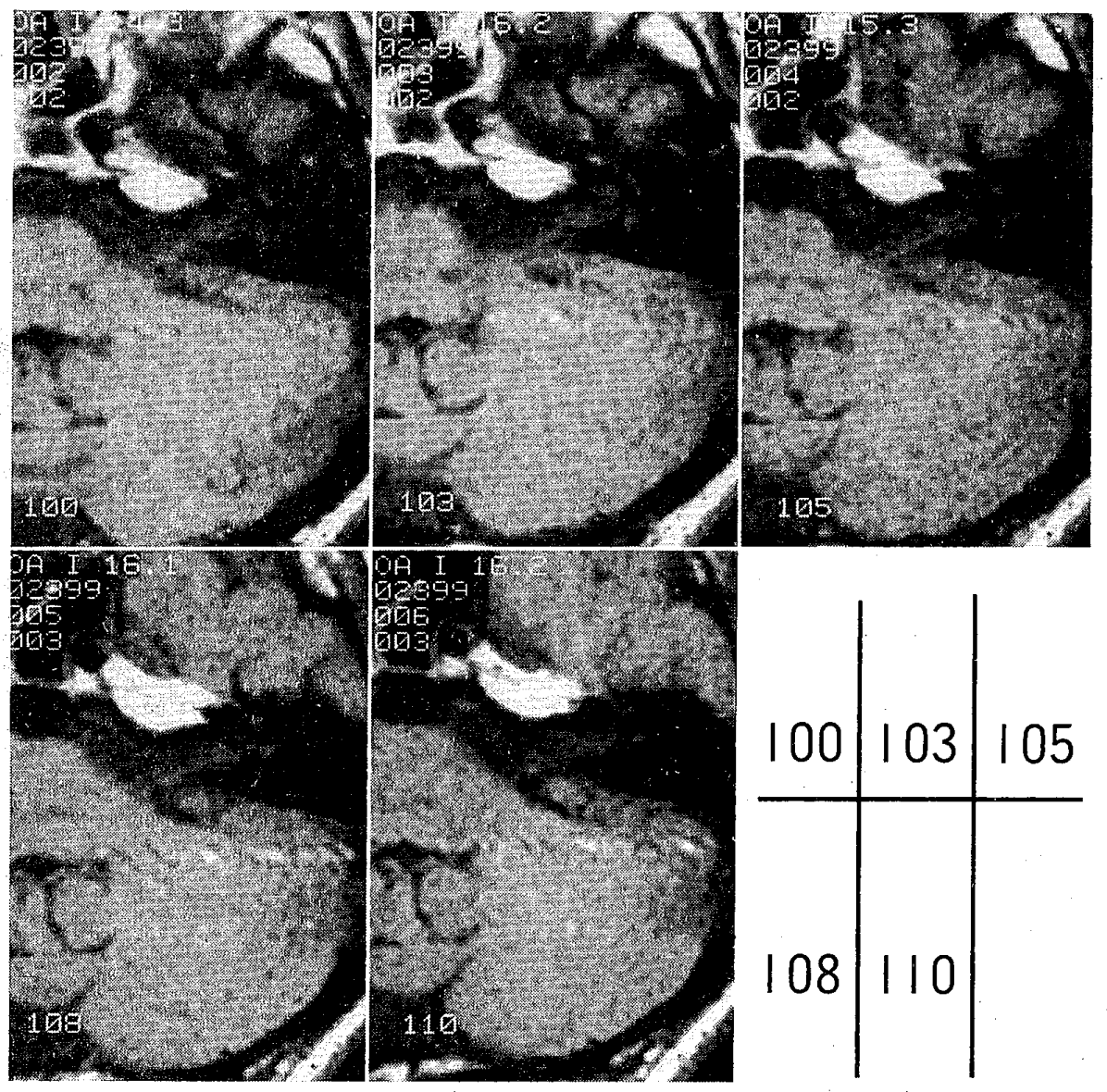

Fig. 6 We have a clinical example of the images in which the angle is shifted a little compared with the excellent images. The result was that 105 is optinum as the excellent image.

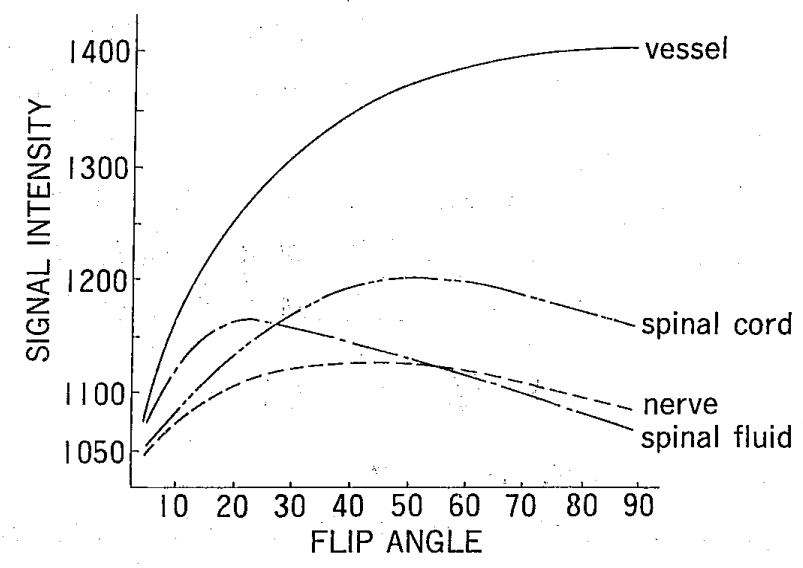

Fig. 7 The relative signal intensity by changing the Flip angle

The signal intensity of the facial nerve and blood vesseel was measured for the correspondence of flip angle. In comparison, we also measumed the intensity for spinal cord and spinal fluid.

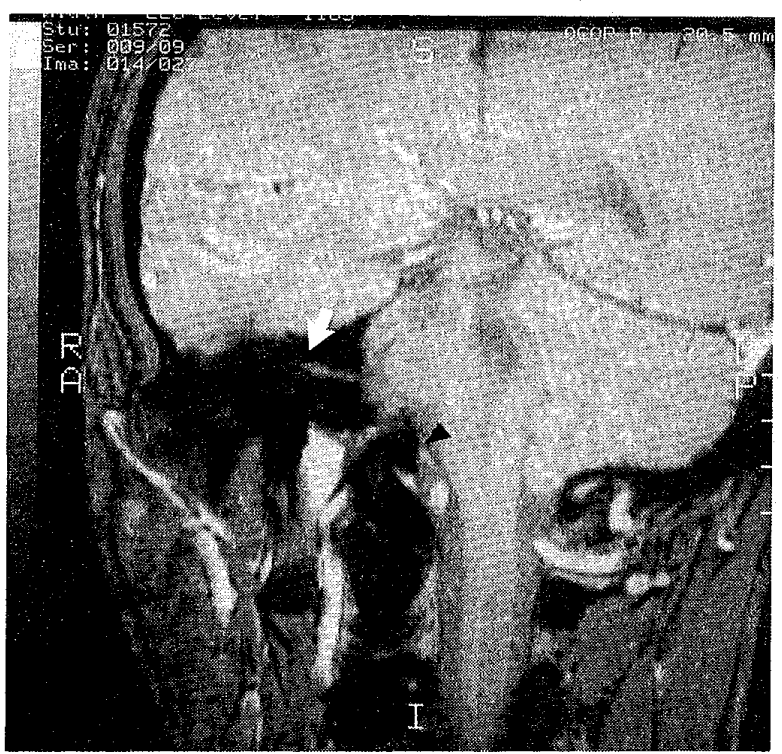

Fig. 8 Case 1 The oblique sagittal image of the normal control with GE method The blood vessel was not observed near the facial nerve. + facial nerve blood vessel 


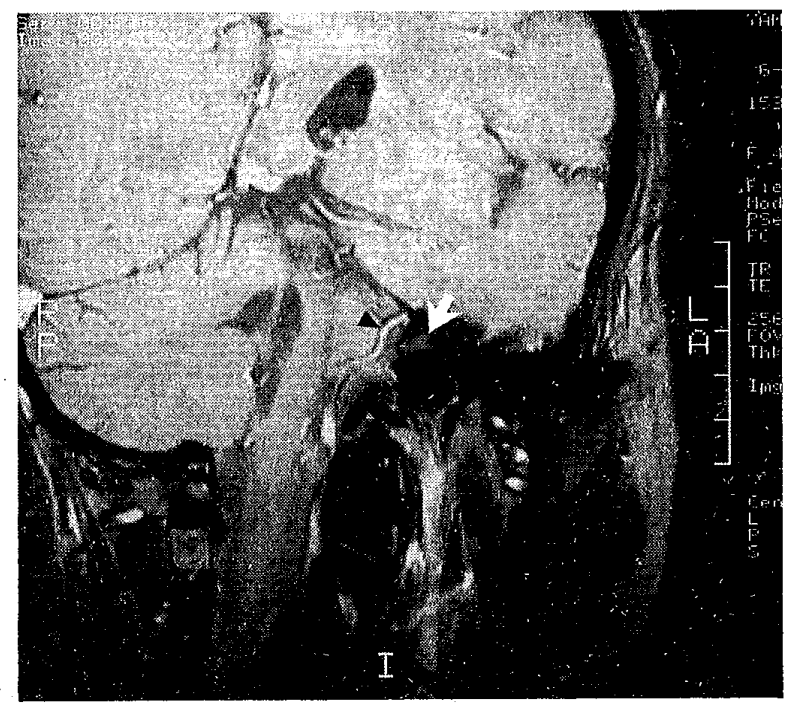

Fig. 9 Case 2 The oblique sagittal image of the hemifacial spasm with GE method It is visualized that the blood vessel compresses the facial nerve near the root exit zone.

$\leftarrow$ facial nerve 4 blood vessel

症例 2 同様, MRI 検查後, 神経血管減圧術を施工して いる. Fig. 10-a は GE 法による斜位矢状断を示す. 顔面 神経に平行した圧迫血管を認める. Fig. 10-b は SE 法に より GE 法と同一面を撮影した画像である．顔面神経の 描出には優れているものの, 血管はフローボイドとなり
確認しにくくなる。また, Fig. 10-c 怯同一症例の GE 法 による横断像を示す，圧迫血管はあるものの, 確認しに くく, 神経との位置関係の把握も難しい.

なお，症例 2,3 とも術中所見において MRI 所見と同 様であることを確認している。

\section{5. 考察}

MRI の進歩により神経と血管の両者を直接的に描写 し診断することが可能となった. MRI による半側顔面㽷 奚の検査法は以前より報告があるが, 撮影方向が横断像 または冠状断像での方法のため, 描出される圧迫血管は 比較的太い椎骨動脈の場合であった，微細な神経と細い 動脈 (PICA，AICA など) の両者を同時に描出し位置関 係を把握するため, 横断像と斜位矢状断像の 2 平面にて 観察した。

2 平面の撮影を迅速に行うためには，横断像での神経 を確実に描出しなければならない。そのため, 神経の描 出に優れている SE 法のT1強調像を用いた。 また, 空間 分解能に優れている3D 法による撮影も検討したが,スラ イス面選択の融通性にかけるため今回は使用しなかった。 横断像を撮影するための位置決めには, 矢状断像と冠状 断像の 2 平面より位置決めを行う double angle 法 ${ }^{9)}$ が 最良であると考えるが，機種により制限があるため汎用 性に欠ける。このため矢状断像または冠状断像より位置

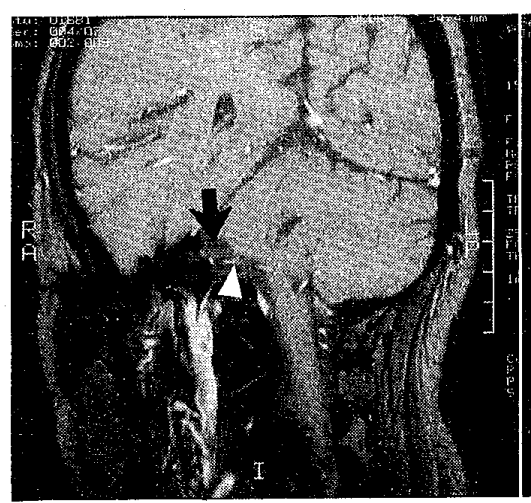

(a)

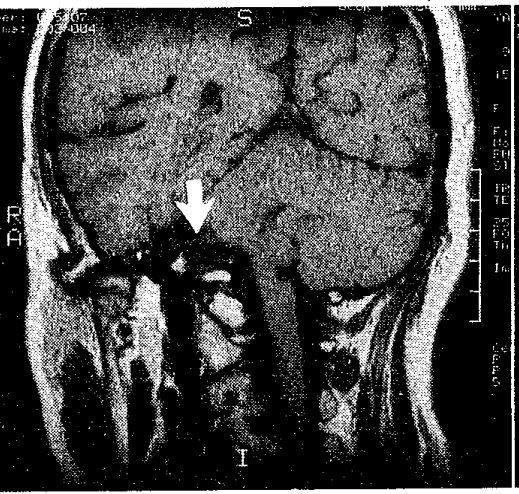

(b)

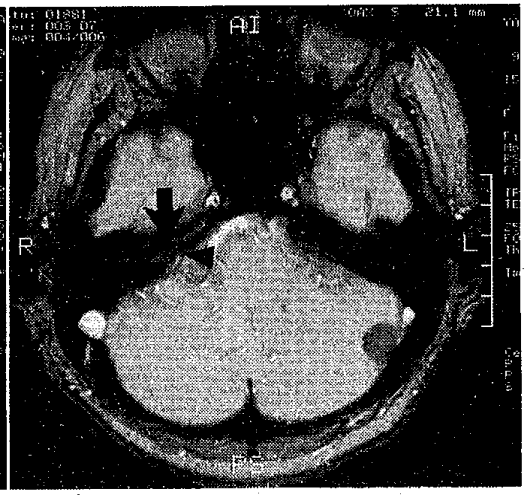

(c)

Fig. 10 Case 3 Image of the hemifacial-spasm patient

a, Oblique sagittal image with GE methed

It is visualized that the vessel was compressed parallel to the facial nerve.

$\leftarrow$ facial nerve 4 blood vessel

b, Image with SE method taken for the same slice of GE method was used In spite of superior description to facial nerve, the blood vessel is not described clearly due to the Flow Void Effect.

c, Axial image with GE method

The compressed vessel is not discribed clearly, and it in difficult to observe relations between a nerve and a vessel. 
決めを行なわなければならないが, 冠状断像からの位置 決めは解剖学的に神経の走行を考えると不適であり，矢 状断像より位置決めを行った。

撮影の位置決めを正確に再現性良く行うためには基準 線が必要である. 矢状断像からは, 通常 OM-Line (Orbital Meatal Line) を基準線とするが，設定にバラ ツキがあり，簿いスライスの検查において正確性に問題 があるため ${ }^{10)}$, 神経の走行に関係が深くかつ明膫な延髄 後縁を基準線として設定した。設定した基準線と横断面 との関係を調べるため,約700例の頭部ルーチン検査のフ イルム上にて再検討を行い，顔面神経（聴神経も含む） の描出にすぐれていた76例について, 両者のなす角度を 測定した結果，105度を中心とし約90〜120度の間に分布 していた. なお, 顔面神経の描出範囲が幅広い理由は, スライス厚 (頭部ルーチン検査のスライス厚は $7 \mathrm{~mm}$ ) が 厚いため, また描出率が低い理由として, パーシャルボ リューム効果とスライス間隔が $3 \mathrm{~mm}$ あること, またデ イスプレイ条件が頭部の設定であるためと考えられる.

次に基準線より「105度」のスライス角度が本検查にお いてどの程度の正確性があるかを検討した結果，90\%程 度は次に行う斜位矢状断像の位置決めが可能な像であり, 血管による神経の圧迫がある場合においてもスライス設 定角度は適応できる。

しかし本撮影法にて横断面を撮影した場合，10\%程度 は神経の描出が不能である．神経の描出許容範囲は 4 〜 5 度であり,描出できない場合には, 100 度もしくは110 度にて撮影することにより，神経は描出される。

横断像にて描出されている顔面神経を基に斜位矢状断 像の撮影を行うことにより，脳幹出口より内耳道入口ま での神経が描出でき，GE法にて撮影することにより Fig. 10 の症例のごとく，血管が高信号となるため PICA, AICA な゙の細い血管の場合でも確認が可能と なった。また GE 法の撮影条件を榆討した結果, TE 20 msec (最小時間), TR は300 msec が神経の描出能に優 れ, $300 \mathrm{msec}$ 未満では S/N 比, コントラストの低下より 神経の描出も低下した。 また Flip angle を変化させても 血管は常に他の組織より高信号であり，神経は45度付近 で信号が最大となり, 両者の組織間コントラストも大き くなり, TE : $20 \mathrm{msec}, \mathrm{TR}: 300 \mathrm{msec}$, Flip angle, 45 度が最良条件となった。

顔面神経の撮影では検查目的によって表面コイルを用 いるが，本法は神経の出口部を対象とするため頭部専用 コイルを用いた．本撮影条件によるファントム実験での $\mathrm{S} / \mathrm{N}$ 比測定では, 深さ $4 \mathrm{~cm}$ までは表面コイル(直径 5 イ
ンチ）が：それ以上では頭部専用コイルが優位であった。 半側顔面㾏孌の画像診断において MRI が確立され, CT, 椎骨動脈造影をせず血管減圧術を行えることは，被 検者にとってたいへん有益であると考える. 本法は三叉 神経痛の検查として応用が可能であることも確認してい る。また延髅後縁に設定する基準線は，他の脳神経の撮 影にも応用可能である.

\section{結 語}

1) 半側顔面痙摹の術前検査として MRIによる撮像法 を考案し，その有用性について報告した。

2）二連の検查を正確に行うため，基準線を延髄後縁に 設定しこれより105度の角度にて撮影することによ り，神経の水平断面を再現性よく描出することがで きた。

3）神経と血管の両者を描出する撮影条件は GE 法が優 れていた。

4）今後, 他の脳神経の描出も検討したい.

謝 辞

本研究にあたり, 御指導を賜りました本学脳神経外科, 永関慶重先生に心から感謝したします。なお，本論文の 要旨は第47回日本放射線技術学会総会 (1991年 4 月京都) にて発表した。

\section{文献}

1）佐々木亮，他：三叉神経痛および顔面痙攣における Vascular compression $の$ 臨床的意義, 脳神経外科, $9,473-481$, (1981)

2) Gardner, W.E. and Sava, G.A : Hemifacial spasm. A reversible pathophysiologic state. J. Neurosurg, 19, 240-247, (1962)

3）欅 篤，他：顔面痙攣症患者における MRI の有 用性, CT 研究，12，433-438，(1990)

4) Tash RR, Kier EL and Chyatte D: Hemifacial spasm caused by a tortuous vertebral artery: MR demonstration. J Comput Assist Tomogr 12, 492-494, (1988)

5）児玉晋一, 他：顔面痙攣に抢ける MRI の有用性, 第 12回脳神経 CT 研究会抄録集, 110，(1989）

6）山内康雄, 他：神経血管圧迫症候群の MR angiography，第17回日本磁気共鳴医学会大会抄録集, 133, (1991)

7）福島孝徳：顔面痤攣, 三叉神経痛に対する後頭蓋 
神経血管減圧術 (Jannetta 法), 脳神経外科, 10, 1257 $-1261,(1982)$

8）永関慶重, 他：半側顔面病卛に対する神経血管隇圧 術の治療成績, 山梨医学第16号，199-123，(1988）

9）佐藤光也，他：頭部横断面 MRI に於ける再現性の
検討：第 2 報 内耳道（聴神経）撮影について，日 放技秋季抄録集，46，128，(1990)

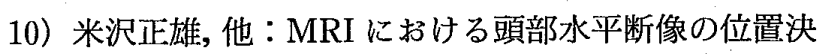
めに関する一考案, 日放技学誌，44（5)，547-551， (1988) 